\title{
Aid workers fear impending disaster in Basra
}

Quirin Schiermeier and Tobias Kramer

The siege of Basra seems to have caught out health officials working with international aid organizations. As Nature went to press, coalition forces had surrounded Iraq's second-largest city, and water supplies to around half of the 1.7-million population had been cut off for over a week. But aid agencies expected humanitarian problems to be concentrated in northern Iraq, and so lack the staff and equipment to contain any problems in Basra.

Iraqi officials say that there were no reports of cholera, typhoid or dysentery in the city last week. But experts with the World Health Organization (WHO) warn that deteriorating sanitation, water contamination, and increasing heat and humidity mean that there is an extremely high risk of an outbreak of diarrhoeal diseases. The hundreds of thousands of children in the city, many of whom are suffering from malnutrition, are particularly at risk.

"We are on the highest alert," says Ghulam Popal, head of the WHO's office in Baghdad, which coordinates the activities of the organization's 327 Iraqi medical staff.

The WHO has 15 emergency health kits - each containing basic needs for 10,000 people for three months - in place in Baghdad, and others are stored in northern Iraq. But the organization has no staff or kits in Basra, so the population there will have little or no access to the equipment, which includes antibiotics, dehydration solutions

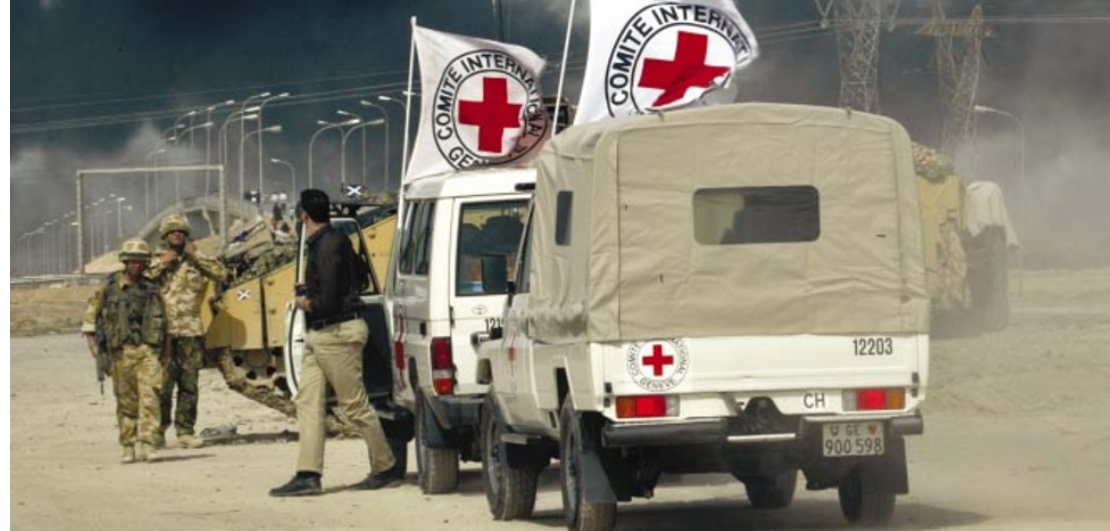

The Red Cross is currently the only aid organization with access to the beleaguered city of Basra.

and water-purification tablets - all of which are vital to combat diarrhoeal diseases.

"You go where you think you'll be needed, and where it is reasonably safe for your own people," says Barry Sandland, a Brusselsbased spokesman for Médecins Sans Frontières, a charity that has sent a team of six doctors to Baghdad. "But at the end it is just guesswork."

WHO officials believe that few people in Basra have access to public-health services. With the city's hospitals overloaded with wounded civilians, possible epidemics are likely to be a secondary consideration for the local health authorities, says Jim Tulloch, the WHO's regional health coordinator in Amman, Jordan.
A WHO rapid-response team in Baghdad is waiting for permits from the Iraqi authorities to travel to Basra, some 500 kilometres south of the Iraqi capital. The group will then have to decide if it is safe to make the journey. "We need immediate access to the city to assess the risk of an epidemic and, in the case of an outbreak, identify its cause and start medical treatment," says Popal.

Currently, the only international aid organization with access to Basra is the Red Cross, thanks to safety guarantees from the Iraqi army and the coalition forces. According to a Geneva-based spokesman, attempts to repair Basra's main water station are under way, but the water supply was still worryingly poor at the beginning of this week.

\section{China joins investigation of mystery pneumonia}

\section{David Cyranoski, Tokyo}

The World Health Organization (WHO) has confirmed that it has managed to enlist China in the international investigation of the mystery pneumonia known as severe acute respiratory syndrome (SARS).

But even as agreement was reached, leading Chinese researchers clashed with WHO investigators over the probable cause of the illness.

SARS arose in East Asia and, according to WHO figures on 31 March, it has so far spread to 13 countries, infecting 1,622 people, 58 of whom have died. One of the recent casualties was Carlo Urbani, an Italian physician working for the WHO, who identified the first case of the disease while treating patients in Vietnam.

Researchers and public-health officials now assume that SARS is the same disease as that which struck the Guangdong province in southern China late last year. Initially, Chinese officials said that the epidemic had infected about 300 people and had petered out in February (see Nature 422, 247; 2003). But last week, they admitted that by the end of February it had infected at least 806 people, causing 34 deaths.

An international investigation coordinated by the WHO has identified two virus families - coronaviruses and paramyxoviruses - as the possible cause of the epidemic, although some believe that the illness may involve a combination of both families. But Tao Hung, a researcher at the Institute of Virology at the Chinese Academy of Preventative Medicine in Beijing, who is heading the Chinese investigation of the epidemic, says that his results point in another direction - a Chlamydia-like bacterium. He says he has found traces of Chlamydia in samples from organs taken from five people who died from SARS and from 30 infected patients.

But researchers inside and outside China dispute that the normally non-lethal
Chlamydia could exact such a heavy toll. "It would go against common sense," says Masato Tashiro of the National Institute of Infectious Diseases in Tokyo, one of the WHO's investigators.

"From a clinical point of view, it cannot be Chlamydia," says Nan Shan Zhong, a doctor at Guangzhou Medical College in Guangdong, who is advising the government on the outbreak in the province. He adds that antibiotics against Chlamydia have proven ineffective in treating the syndrome. "I do not believe the disease is really under control," he says.

In the agreement reached on 30 March, a WHO delegation led by John Mackenzie, a virologist at the University of Queensland, Australia, convinced China to become a full participant in the WHO operation. This will mean full updates, sharing resources, and allowing WHO officials to visit doctors in Guangdong - something that has been repeatedly promised but has yet to occur. 